\title{
THE ARTICLE: ORIGIN, TYPES AND FUNCTIONS
}

\author{
Mizetska V. Ya., Korkishko S. V.
}

\section{INTRODUCTION}

The article is one of the auxiliary parts of speech used in the combination with the nouns for rendering different grammatical meanings including the indication categories "definiteness" and "indefiniteness".

As the functions of articles are not reduced to the indication of definiteness and indefiniteness the more accurate definition will be as follows:

Articles are markers in the nominal domain whose main function is to encode the referential function of the noun that they occur with.

The articles are words whose semantic meanings completely coincide with their grammatical ones. This fact gives some scholars a foundation to qualify the words of this kind as function words (Rayevska).

This paper is devoted to the different aspects of origin, structure and functioning of the articles.

Many scientists investigated these problems (V. Friedman ${ }^{1}$, G. Guillaume ${ }^{2}$, M. Haspelmath ${ }^{3}$, G. Kramsky ${ }^{4}$, etc.). There are separate observations concerning different aspects of their usage in different languages.

But the all - round classification of the articles is not worked out.

The task of this paper is to systematize these ideas and facts concerning articles for creating a foundation for the comprehensive classification. Some versions of their origin also underwent the critical analysis in this paper.

1 Friedman V. "One" as an indefinite marker in Balkan and Non - Balkan Slavic/ A. Timberlake, M. Flier (eds.). American contributions to the $13^{\text {th }}$ International congress of the Slavists Bloomington : Slavica, 2003. P. 93-112.

${ }^{2}$ Guillaume G. Le problem de l'article et sa solution dans la langue francaise. Paris : Hachette, 1999.

3 Haspelmath M. Explaining article - possessor incompatibility: economic motivation in noun phrase syntax. Language. 1999. Vol. 75. № 2. P. 227-243.

4 Kramsky G. The article and the concept of definiteness in language. The Hague : Mouton, 1972. 
The attention here is concentrated on the languages belonging to different types and families including Indo-European languages (Romance, Germanic, Slavonic groups, etc.). There were also analyzed the articles of such languages as Turkish, Arabic, the American Indian languages, the languages of African continent (Swahili, Somali, etc.).

The comparative method is widely used, which allows to verify the common and specific features concerning the articles.

\section{Types of articles}

The articles can be classified into the following types:

- the definite articles (En. the; Fr. le, la, les; Germ. die, der, das, etc.);

- the indefinite articles (En. a/an; Fr. un, une; Germ. ein, eine, etc.);

- zero articles (in the English language it is used with the nouns in the plural if in the Singular the word takes the indefinite article: an apple apples);

- partitive articles (Fr. $d u$, de la, which are used with the uncountable nouns: Voulez-vous du café?).

In the Russian language for this purpose they usually use the genetive case: Отрезать вам хлеба? (Should we cut some bread for you?).

Sometimes the special partitive form is used: Хотите чаю? (Would you like some tea?).

The definite article is used in the individualizing function, the indefinite article is used for the characteristics of the object as one of the representatives of a certain class of items. Besides these general functions the articles fulfil other functions, e.g. in the English language the definite article can denote the whole class of objects, the whole type of the homogeneous objects or entities including animals, e.g. the word "the tiger" shows the kind of the animal alongside the definite concrete animal.

Division into the definite and indefinite articles can be found in the French language (le / la - the definite articles, un / une - the indefinite articles), in the German language ( $\underline{\text { in }}$ - the indefinite article, $\underline{\mathrm{der}}$ - the definite article, etc.).

In the English language we find the same dichotomy (an apple the apple).

Articles may have the gender seme. For example, in the French language there are two genders - masculine and feminine (mase. $\underline{\text { le }}$, $\underline{u n}$; fem. $\underline{l a}, \underline{u n e}$ ), though in the plural this gender category is not actualized (les is used with the nouns of both genders). 
In the German language there are three genders and the article actualizes this gender category: fem. die (Sonne), masc. der (Vogel), neut. das (Messer).

In the English language articles do not have the gender differentiation: the articles the and $\underline{a / a n}$ are used irrespective of the sex of the subject they define: a man, a woman; the uncle, the aunt, etc.).

In some languages the category of number is also actualized, e.g. in the French language the articles le/la denote singular objects, while in the plural they are transformed into the article les.

In the English language the category of number is actualized partially: for the definite article the this quality is irrelevant (the applethe apples), while for the indefinite article it is relevant: in the singular the article $\underline{a / a n}$ is used, while in the plural there appears the so-called zero article (a table - tables).

All the languages can be divided into article languages and languages without articles. The article languages include the Romance languages (French, Italian, Spanish, Portuguese, etc.), the Germanic languages (English, German, Dutch, Norwegian, Swedish, etc.), some Slavic languages (Bulgarian, Macedonian). This enumeration can be continued. In some languages (Swahili) the articles are seldom used. Modern Russian languages and Modern Ukrainian, the most part of the other Slavonic language (with the exception of Bulgarian and Macedonian), Sanskrit, Latin, Chinese, Japanese do not have any articles. Many Turkic languages (Tatar, Bashkir, Chuvash), many Uralic languages (Finnic and Saami, Hindi, Tamil) lack articles too.

It should be noted that some investigators (Bogoroditsky, Shachmatov, etc.) believe that the Russian particle -mo (to) in such phrases as «Колька-то уже уехал!» (Nick has gone!) in its functional qualities is close to the postpositive articles in the Bulgarian language. They believe that the above - mentioned formant fulfils not only the expressive function but also the function of determination, that is the function of the definite article ${ }^{5}$.

The other researchers (L. Kuzmina, Y. Nemchenko, V. Trubinsky ${ }^{6}$, etc.) believe that the formant $-\underline{m o}$ fulfils only the emphatic function.

${ }^{5}$ Касаткина Р. Артикли, предартикли и псевдоартикли в славянских языках. Славянское языкознание : XIV Международный съезд славистов / А. Молдован (ред.). Москва : Индрик, 2008. С. 305-321.

6 Кузьмина Л., Немченко Е. К вопросу о постпозитивных частицах в русских говорах. Материаль и исследования по русской диалектности. Москва, 1962. Т. III. С. 3-32 ; Трубинский В. Об участии постпозитивной частицы $-\underline{m o}$ в построении сложного предложения. Севернорусские говоры 1. Ленинград, 1970. С. 48-64. 
As a main reason for such a point of view they put forward the idea that the formant $-\underline{m o}$ is used not only with the nouns but also with the other parts of speech, including the adverbs, adjectives and pronouns.

The question concerning the state of the element $-m o$ in the Russian language is still disputable, though we share the opinion of the second group of scholars who do not qualify this formant as the article for the reasons mentioned above.

There are languages, e.g. Welsh, Arabic, Icelandic, Hebrew, Armenian, the artificial languages Ido and Esperanto, which have only the definite article, but there are not any indefinite articles in them.

In some languages there is only the indefinite article as in the Turkish language. The indefinite article here coincides with the numeral bir.

In the languages without articles the category of definiteness / indefiniteness is compensated for by different means.

The absence of the article in the Russian language is compensated for in the following ways:

1) the use of the demonstrative and possessive pronouns (эта девушка - this girl; моя сестра - my sister);

2) the order of the words. Comp.: «Из окна выглянула девушка» and «Девушка выглянула из окна». In the latter case due to its position of the theme the word «девушка» suggests the idea of definiteness (a certain girl).

When the word «девушка» has the final position, that is the position of the rheme, it suggests that some unknown girl is mentioned;

3 ) the word $\underline{\partial u \mu}$ (one) which is the marker of indefiniteness (Жилбыл один иарь - There lived one tsar). In this function the Russian word loses its main meaning of the numeral and turns into the analogue of the English indefinite article (a/an);

4) the indefinite pronouns: некий человек, какой-то человек (some man).

The presence of articles in several languages of the family does not mean that all the other languages of this family also have articles.

For examples, in many Semitic languages articles are used but you will not find them in the Ethiopic language though it is one of the Semitic languages.

To the markers of definiteness (determination) in the English language belong not only articles but also possessive pronouns (my house) and demonstrative pronouns (this house) as in many other languages.

These classes of pronouns in the English language do not admit duplication of the meaning of definiteness expressed by the definite article. 
M. Daniel and V. Plungian called the phenomenon when this duplication is prohibited "contextual displacement (ousting)". 7

But this restriction does not have the universal character. There are languages which admit this duplication, for example, here belong such languages as Hebrew, Armenian, New Greek in which the marker of definiteness (articles and their analogues) may be used with the other determiners simultaneously.

Proper names also belong to the group of words which actualize the category of definiteness.

Nevertheless, in some languages the article is not used with proper names while in the other languages the combination of two markers of definiteness - the article and proper name - is not possible or even prohibited.

For example, the article may be used with proper names in New Greek. The article o here is used even with the name of Jesus Christ.

The articles are also used with proper names in Portuguese (a Maria) and some other languages. In such languages, as French and Italian the definite articles are used with most names of countries (la France, l'Italia, etc.).

In the English language in some cases proper names require the usage of articles while the other ones do not take them.

There are certain rules of usage for the articles with proper names in the English language but they are not stable and have a lot of exceptions.

In many cases the idea of singularity or plurality of objects named is the dominant one and this factor stipulates the choice of the article (definite or zero). The definite article is used when proper names denote a group of homogeneous objects: The Alps, The Hebrides. At the same time the single objects of the corresponding groups do not take the article, e.g. Elbrus, Greenland, etc.

The combinations of proper names with the preposition "of" require the usage of the definite article: the Isle of Man, The Bay of Biscay, etc.

It is necessary to use zero articles if the proper name includes the nouns in the possessive case. Compare: the Hilton (hotel) and Bertram's Hotel.

But in the overwhelming majority of cases the domineering role belongs to the tradition. For example, traditionally the names of water

7 Даниэль М., Плунгян В. Обязательность и контекстная вытеснимость (к описанию грамматической периферии. Известия Российской академии наук. Серия «Литература и язык». 1996. Т. 55. С. 61-66. 
masses are used with the definite article: the Black Sea, the Thames, the Pacific Ocean, the Great Lakes, though the names of single lakes do not take the article if the word "lake" is present: Lake Leman.

The names of cities, streets, squares and bridges in English by tradition are used with zero article (the Strand, the Hague, etc. are exceptions), while the names of museums, theaters, cinemas, galleries take the definite article as well as the names of ships, newspapers and magazines.

As we see, the rule of contextual displacement (ousting) in the English language when it concerns Proper names does not work.

\section{Version of articles origin}

Articles as determinaners of nouns were formed in different ways. They are not used in Ancient Indian, Ancient Greek, Latin.

They did not exist at the early stages of the Greek language including the language of Homer. Regular use of articles in the Greek language appeared only in the Attic prose.

E. Cassirer believes that the definite article appeared comparatively recently, later than the indefinite article ${ }^{8}$.

$\mathrm{He}$ also believes that the development of the articles went from the concrete to the abstract.

In Ancient times it was a common thing to use the articles specifying different semantic groups. This tendency is preserved in several languages. For example, in the Indonesian languages alongside the subject article there functions the special personal article, used with the names of individuals and the names of family relations.

In the Indian language Poncha there are special articles for the horizontal and round objects. Their choice depends on the fact whether the person sits, stands or goes.

The concrete visual meanings of the articles are preserved in the Somali language ${ }^{9}$. There are three forms of the article with different vowels $(-a,-i$ and $-o / u)$. The choice of the article is stipulated by the space factors.

The articles with the ending - $\underline{a}$ show that the object defined is situated in the nearest distance from the speaker. The article ending in the $\underline{-O}$ is

\footnotetext{
${ }^{8}$ Кассирер Э. Философия символических форм. Москва : Академический проект, 2011. Т. 1 : Язык. С. 271.

${ }^{9}$ Tiling Maria von. Die Vokale des Bestimmten Articles im Somals. 3eitschrift für Kolonialsprachen, 1918. IX. S. 132.
} 
used when the speaker mentions the objects situated at a certain distance from him or her, but these objects are within his/her field of vision.

The articles with the ending $-\underline{i}$ are the markers of the objects which are not in the visual field of the speaker.

Standard Basque distinguishes between proximal and distal definite articles in the plural. As we see, the space factor here is also very important.

Cassirer posits that the trigger for the appearance of the articles is the necessity to fix the space position of the object. The functioning of the "spatial articles" in some languages the researcher puts forward as the main argument in favour of his point of view concerning the origin of the articles from the space indicators. He believed that the first articles were the so- called spatial articles.

The majority of scholars believe that the definite articles are derived from the demonstrative pronouns with the meaning that. It shows that they agree with the general conception of Cassirer.

One of the arguments in favour of this version is the fact that in the Romance languages which were formed on the basis of Latin the definite articles developed from the demonstrative pronoun "ille' (Fr. le, Sp. el, It. $i l$, etc.). It should be noted that in Latin itself the articles are not used at all. The English definite article the derives from the old English demonstrative pronoun $\underline{s e}$.

The origin of the indefinite articles according to the domineering opinion among the scholars is connected with the number (numeral) "one". For example, the indefinite articles in the Romance languages "un, una, uno" derived from the Latin word "unus".

Many scientists believe that articles existed in the Proto-Slavonic language and their relics can be found in modern Russian adjectives.

In the Old Slavonic language there were used the articles $\underline{u, e, r}$ (in the modern pronunciation) of the masculine, feminine and neuter genders correspondingly.

The article was used after the adjective before nouns but these first adjectives were short forms. The articles used after these short adjectives did not have the stress and gradually joined and merged with the previous adjective: добро + е дъело (good affair) - доброе дело; добра + я сестра (good sister) - добрая сестра.

Thus, full adjectives were formed as a result of merging short adjectives with the components which many researchers qualify as articles. 
Gradually the meaning of determination expressed by the article in the Russian language disappeared. Nowadays short adjectives are not used in the function of the attribute as it was before. They preserved this function only in some set expressions, such as: на босу ногу (barefooted), красна девица (beautiful girl), etc.

In the Ukrainian language short adjectives are not used at all.

The question of the units $\underline{u, e, r}$ and their functions in Old Slavonic remains disputable as some researchers (Remnyova) ${ }^{10}$ qualify them as demonstrative pronouns.

\section{Structural models of word combinations with articles}

The article may have different positions in the sentence.

In some languages it may be placed before the word it defines. In this case it is called a prepositive article.

In some other languages it may be placed after the word which it defines as in the Danish language. Moreover, it may even merge with the word it defines, e.g. Solen (the sun) where en is the so-called suffixal (suffixed) postpositive article.

The suffixal articles are also used in such languages as Albanian (зод - зод $\underline{u}$, which means "bird"), Aramaic (shalem - shalma which means "peace"), Icelandic (hestur - hesturinn which means "horse").

Postposition is typical of the Bulgarian languages, e.g. дървоto (tree). But if the adjectives or numerals accompany the noun, the article joins the first attribute: за голямата бяла топка (with the large white ball ${ }^{11}$ ).

The suffixal article is also used in the Latvian and Lithuanian languages. These articles are joined to the attribute if it is present, e.g. Lith. stalas (table) - baltas stalas (the white table).

There are also cases of the double definite articles when one of them as an independent word is placed in preposition, while the second one joining the defined word is placed at the end of this word as its final.

This model is characteristic of the Northern Germanic languages (Swedish, Norwegian, Danish, etc.) For example, in the Danish language the double article can be found in the word combination det gamle huset (the old house). The first article here is the independent word in

10 Ремнёва М. Старославянский язык : учебное пособие. Москва : Академический проспект, 2004. С. 352.

${ }^{11}$ Mayer G. The definite article in contemporary standard Bulgarian. Wiesbaden : Harrassowitz, 1988. 
preposition, while the second one is the suffixal article, joined as the final to the word it defines.

The prefixal articles are not used frequently. Rare cases of their usage can be found in Hebrew, where the formant $\underline{-h a}$ is joined to the word it defines. Here it fulfils the function of the definite article, e.g. yeled hayeled (the boy).

Prefixed definite articles are also used in the Maltese language: dar (a house) - id-dar (the house), ras (a head) - ir-ras (the head).

Sometimes the exponents of the article are infixes. For example, in Sumu (Nicaragua) the article appears as an infix: e.g. waki $-\underline{n i}-s a$ (the banana) in contrast to the form without the article - wakisa (a banana).

\section{Grammatical and semantic function of the articles}

The article fulfils the following functions:

1) function of the noun indicator / marker. Due to this fact in many languages the article appears before the word and transforms it into the class of nouns. The phenomenon when the word passes into another category and gets into a new paradigm without changes of its initial morphological structure is known as conversion. Thus, the article is a participant in this process. For example, in the German language Schreiben means "to write", while das Schreiben means "the writing"; in the French language diner means "to have a dinner" while le diner means "a dinner"; in the Spanish language cantar means "to sing" while $\underline{e l}$ cantar denotes "a song".

Conversion is widely spread in the English language. The markers of the Infinitive in this case are replaced by the definite or indefinite article: to call - a call, to ride - the ride ( etc.).

The function of the substance marker is not universal.

In some languages the article may be used not only with the nouns but also with the pronouns, adverbs and even conjunctions. Such a phenomenon can be found in the Ewe language where the article is posed after the word it defines. ${ }^{12}$ We suggest that such units should be qualified as pseudo - articles;

2) function of the differentiation of the grammatical category of definiteness / indefiniteness (determination / indetermination) when there exist the pair articles: Eng. an - the; Germ. ein - der; Fr. un - el; Sp. una - la; It. uno - il, etc;

${ }^{12}$ Westermann D. Gramatik der Ewe - Sprach. Berlin, 1907. S. 61. 
3) function of the gender differentiation: Germ. der Hausa (the man from the tribe called Hausa; die Hausa (the woman from the tribe of Hausa);

4) function of the case differentiation.

In some languages, for example, in the German language, the article agrees with the noun not only in the number and gender, but also in the case, that is the articles decline together with the nouns.

For the English language the declination of articles is not relevant. Despite its deep case the article does not change: on the table, without the table, near the table, etc.

Some researchers try to find the correlation between the presence/ absence of the articles and the presence/ absence of cases.

We believe that there is not a distinct correlation between these linguistic categories. The idea of the inversely proportional dependence is not supported by the concrete facts.

For example, in the languages with the close affinity Bulgarian and Macedonian the case system of the nouns disappeared but the articles are preserved $^{13}$.

In Hungarian there are a lot of cases, but both definite and indefinite articles are used;

5) function of the number differentiation.

The article also serves the marker of the number like in the French language: le/la mark the singular while les is used with the nouns when it is necessary to show the Plurality.

Articles may fulfil only one function (monofunctional articles) or combine several functions (multifunctional articles). In the German language the article is cumulative as it fulfils three functions simultaneously: it actualizes categories of gender, number and case at one and the same time. Moreover, it also shows definiteness or indefiniteness.

In the French language the article $\underline{l e}$ simultaneously actualizes the category of number (singularity) and gender (masculine);

6) function of homonymic differentiation.

In some languages there exist homonyms the meaning of which can be defined only due to the article. The semantics of such words depends

${ }^{13}$ Weiss D. The rise of an indefinite article: the case of Macedonian. What makes grammaticalization? / W. Bisang et al. (eds). Berlin : Mounton de Gruyter, 2004. P. 139-165. 
on the gender article which is the marker of the corresponding material meaning of the noun.

Compare: Germ. die Steuer - with the feminine article it means "the tax"; das Steuer - with the neuter article it means "the steering wheel; rudder"; Sp.: el pez means "fish" (masculine article) but la pez means "resin, tar" (feminine article).

\section{CONCLUSIONS}

There are serious arguments in favour of the idea that the development of articles went from the concrete- visual concepts to the more abstracts ones. It is quite possible that the necessity to fix the distance between the object and the speaker was the trigger for the appearance of articles.

The data obtained also speak in favour of the idea that the definite articles derived from the demonstrative pronouns while the origin of the indefinite articles is connected with the number "one".

The structural models with the articles are variable. The article may be placed in preposition or postposition. Articles may be separate words or sufixal ones, that is finals (enclitics), and prefixal ones (proclitics), which merge with the words defined. Sometimes infixes are also used.

There are cases of duplication of different kinds of articles (separate independent article + suffixal article), which is typical of the Scandinavian languages.

The article may merge not only with the nouns but also with the other parts of speech (mostly adjectives like in the Bulgarian and Macedonian languages).

The functions of articles are much wider than it is usually presented or supposed. They are not only the markers of substantives but also markers of definiteness / indefiniteness, partitiveness, number, gender, case and they are markers of the material meanings of the homonymic units.

They are also markers of distance (the Somali language). Moreover, this function is supposed to be the primary one, that is the spatial articles were the first units which acquired the status of the article.

\section{SUMMARY}

The paper is devoted to the all- round investigation of the articles. The problems of their origin, structure and functioning are in the centre of observation. 
The investigation showed that the development of articles went from the concrete - visual to abstract as it was predicted by E. Cassirer.

The data obtained supported the version that the indefinite article derived from the number "one" while the definite articles derived from the demonstrative pronouns with the meaning "that".

The structure models of the word combinations with the articles are variable.

The article may be a separate independent unit or a suffixal (suffixed) enclitical unit which merges with the words defined. The prefixal articles and infixes are used seldom.

The articles may be placed in preposition or postposition (prepositional and postpositional articles).

In some languages different types of articles may be used simultaneously. Such a duplication is typical of the Scandinavian languages.

Besides its main function (the article fulfils the function of the substantive marker) it performs other functions. It may be the marker of gender, number and case. It may be an exponent of the category of indefiniteness / definiteness. It may also help to differentiate between the meaning of homonymic units.

In some languages (Somali) the article is also the marker of distance between the object and the speaker (the spatial article). Articled may be multifunctional or monofunctional.

There are languages (Indonesian) in which articles may define not only the nouns but also the words belonging to the other parts of speech (mostly adjectives but also adverbs, pronouns and even conjunctions). We suggest that they should be qualified as pseudo-articles.

The further investigation will help to obtain the data for the comprehensive classification of articles in the languages of the world and to confirm the reliability of conclusions with the corresponding figures.

Blg. - Bulgarian.

Dn. - Danish.

En. - English.

Fr. - French.

Germ. - German.

It. - Italian.

Lith. - Lithuanian.

Mc. - Macedonian.

Prt. - Portuguese.

Sp. - Spanish. 


\section{References}

1. Брой В. Развитие систем артиклей в славянских микроязыках в абсолютном языковом контексте. Deutsche Beitrage zum 14 Internationalen Slavistenkongress / S. Kempgen et al. Munchen ; Sagner, 2008. S. 75-88.

2. Булыгина Т., Синёва О. Литовский язык. Москва : Academia, 2006. C. 93-155.

3. Гиппиус А. Морфологические, лексические и синтаксические факторы в склонении древнерусских членных прилагательных. Исследования по славянскому историческому языкознанию / Б. Успенский, М. Шевелева (ред.). Москва : МГУ, 1993. С. 66-84.

4. Даниэль М., Плунгян В. Обязательность и контекстная вытеснимость (к описанию грамматической периферии. Известия Российской академии наук. Серия «Литература и язык». 1996. Т. 55. C. 61-66.

5. Касаткина Р. Артикли, предартикли и псевдоартикли в славянских языках / А. Молдован (ред.). Славянское языкознание : XIV Международный съезд славистов. Москва : Индрик, 2008. C. 305-321.

6. Кассирер Э. Философия символических форм. Пер. с нем. С. Ромашко. Москва : Академический проспект, 2011. Т. 1 : Язык. C. 271.

7. Крамский И. К проблеме артикля. Bопросы языкознания. 1963. № 4. С. 14-26.

8. Плунгян В. Введение в грамматическую семантику : грамматические значения и грамматические системы языков мира. Москва : ЗГГУ, 2011. С. 672.

9. Ремнёва М. Старославянский язык : учебное пособие. Москва : Академический проспект, 2004. С. 352.

10. Chvany C. "On definiteness" in Bulgarian, English and Russian. Selected essays of C.V. Chvany / O. Yokoyama, E. Klenin (eds). Columbus (OH) : Slavica, 1996. P. 128-147.

11. Friedman V. "One" as an indefinite marker in Balkan and Non Balkan Slavic / A. Timberlake, M. Flier (eds.). American contributions to the $13^{\text {th }}$ International congress of the Slavists. Bloomington : Slavica, 2003. P. 93-112.

12. Guillaume G. Le problem de l'article et sa solution dans la langue francaise. Paris : Hachette, 1999. 
13. Haspelmath M. Explaining article - possessor incompatibility: economic motivation in noun phrase syntax. Language. 1999. Vol. 75. № 2. P. 227-243.

14. Hawkins J. Definiteness and indefiniteness : A study in reference and grammatical prediction. L. : Croom Helm, 1978.

15. Kramsky G. The article and the concept of definiteness in language. The Hague : Mouton, 1972.

16. Mayer G. The definite article in contemporary standard Bulgarian. Wiesbaden : Harrassowitz, 1988.

17. Vogel D. Uber den Zuzammenhang von definite Artikel und Ferndeixis. Sprachtypologie und Universalienforschung. 1993. Vol. 46. № 3. S. 222-185.

18. Weiss D. The rise of an indefinite article: the case of Macedonian. What makes grammaticalization? / W. Bisang et al. (eds). Berlin : Mounton de Gruyter, 2004. P. 139-165.

19. Westermann D. Gramatik der Ewe - Sprach. Berlin, 1907. S. 61.

Information about the authors:

Mizetska Vira Yaroslavivna, Doctor of Philology Sciences, Professor, Head of the Foreign Languages Department International Humanitarian University 33, Fontanska doroha str., Odesa, 65009, Ukraine

Korkishko Snizhana Vasylivna, Teacher at the Foreign Languages Department International Humanitarian University 33, Fontanska doroha str., Odesa, 65009, Ukraine 